\title{
Study of Mechanical and Tribological Properties of Al-Si alloy Prepared by Powder Metallurgical technology
}

\author{
Hemant kumar Neopaney ${ }^{\mathrm{a}}$, Santanu Chakraborty ${ }^{\mathrm{b}}$ \\ ${ }^{a}$ B-tech student, Sikkim Manipal Institute of Technology,Majhitar East Sikkim,737136, India \\ ${ }^{b}$ Assistant proffesor,Sikkim Manipal Institute of Technology,Majhitar East Sikkim, 737136,I ndia
}

\begin{abstract}
Aluminium alloys have extensive application in industries. The range of physical properties that can be imparted to them is remarkable. Mixing of Silicon to aluminium tends to increase its strength to weight ratio and wear resistance, and tends to decrease its density and coefficient of thermal expansion. In the present work Al-Si alloy cylindrical pin is produced through powder metallurgy process and experimentation is made to determine the mechanical \& tribological properties of five alloy samples i.e. Al-9wt\%Si, Al-12wt\%Si, Al$14 w t \% S i$ Al-17wt\%Si and Al-21wt\%Si.A composition analysis is done in the testing laboratory to verify the weight\% of Silicon \& Aluminium in the Al-Si alloy. Density test is done by measuring mass \& volume of the alloy samples. Hardness of the alloy samples is measured by taking four indentations with the help of Brinell hardness testing machine and calculating its hardness number. Porosity of the samples is evaluated by considering the density of the sintered component $(\gamma p)$ \& the density of the solid alloy material $(\gamma s)$. Wear tests is conducted using a pin on-disc type wear testing machine (DUCOM wear and friction monitor) and taking sliding velocity and applied load as the parameters.
\end{abstract}

keywords: Aluminium; Silicon; powder metallurgy; Hardness; Wear; Fractional Porosity; Sliding Velocity;

\section{Introduction}

Aluminium ( $\mathrm{Al}$ ) is the second most plentiful element on earth and it emerged as an economic competitor in the engineering applications as early as in the end of the 19th century. The emergence of three industrial revolutions saw the emergence of aluminium and its alloys as one of the most demanded raw materials in the industrial world. In recent years aluminium alloys are widely used in automotive industries. This is particularly due to the real need to weight saving for more reduction of fuel consumption. The typical alloying elements are copper, magnesium, manganese, silicon, and zinc. Surfaces of aluminium alloys have a brilliant lustre in dry environment due to the formation of a shielding layer of aluminium oxide. Aluminium alloys of the $4 \mathrm{xxx}, 5 \mathrm{xxx}$ and $6 \mathrm{xxx}$ series, containing major elemental additives of $\mathrm{Mg}$ and $\mathrm{Si}$, are now being used to replace steel panels in various automobile industries. Thus it becomes all the more vital to study the tribological characteristics of aluminium and its alloys ${ }^{[1]}$.

On the basis of the major alloying element, the aluminium alloys are designated according to the Aluminium Association Wrought Alloy Designation System which consists of four numerical digits ${ }^{[2]}$.

Table 1.1 Designation of aluminium alloys and their applications.

\begin{tabular}{|l|l|l|}
\hline Alloys & Main alloying element & Applications \\
\hline $1 \mathrm{xxx}$ & $\begin{array}{l}\text { Mostly pure aluminum; no major } \\
\text { alloying additions }\end{array}$ & Electrical and chemical industries \\
\hline $2 \mathrm{xxx}$ & Copper & Aircraft components \\
\hline $3 \mathrm{xxx}$ & Manganese & Architectural applications \\
\hline $4 \mathrm{xxx}$ & Silicon & Welding rods, automobile parts \\
\hline $5 \mathrm{xxx}$ & Magnesium & Boat hulls, marine industries \\
\hline $6 \mathrm{xxx}$ & Magnesium and silicon & Architectural extrusions \\
\hline $7 \mathrm{xxx}$ & Zinc & Aircraft components \\
\hline $8 \mathrm{xxx}$ & Other elements & \\
\hline $9 \mathrm{xxx}$ & Unassigned & \\
\hline
\end{tabular}

Addition of Silicon to aluminium gives high strength to weight ratio, low thermal expansion coefficient and high wear resistance. These alloys show improved strength and wear properties as the silicon content is increased beyond eutectic composition. Such properties warrant the use of these materials as structural components in automotive industries. Silicon also imparts high fluidity and low shrinkage, which result in good castability and weldability. Al-Si alloys are designated 4xxx alloys according to the Aluminium Association Wrought Alloy Designation System. The major features of the 4xxx series are:

a. Heat treatable

b. Good flow characteristics, medium strength

c. Easily joined, especially by brazing and soldering ${ }^{[3]}$ 
Many Researchers have worked out on different aspects of Al-Si or other alloy. They also studied about the tribological and other behaviors. In this work, five Al-Si alloy cylindrical pins are produced using powder metallurgy with different compositions (i.e. Al-9wt $\% \mathrm{Si}$, Al- $12 \mathrm{wt} \% \mathrm{Si}, \mathrm{Al}-14 \mathrm{wt} \% \mathrm{Si} \mathrm{Al}-17 \mathrm{wt} \% \mathrm{Si}$ and $\mathrm{Al}-$ $21 \mathrm{wt} \% \mathrm{Si}$ ) and their properties are studied. The properties that are considered in this paper arevariation of density of alloy-samples, fractional porosity of the alloy-samples, hardness number of different $\mathrm{p} / \mathrm{m}$ alloy samples, wear behavior of the alloy samples, wt.\% of Aluminium and Silicon in different samples after all tests are over.

\section{Aluminium Silicon Alloys}

Alloys of Aluminium with silicon as a major alloying element are by far the most important commercial casting alloys, primarily because of their superior casting characteristics in comparison to other alloys. Silicon is good in metallic alloys. This is because it increases the fluidity of the melt, reduces the melting temperature, decreases the shrinkage during solidification and is very inexpensive as a raw material. A wide range of physical and mechanical properties is afforded by these alloys. Binary aluminium-silicon alloys combine the advantages of high corrosion resistance, good weldability, low specific gravity and superior tribological characteristics compared to the other aluminium alloys. These alloys have been successfully used as substitute for cast iron in applications such as pistons and cylinder linings for internal combustion engines, connecting rods and sockets in refrigerant compressors. Although casting of these alloys are somewhat more difficult to machine than the aluminium-copper or aluminium-magnesium alloys, all type of machining operations are routinely accomplished, usually using tungsten carbide tools and appropriate coolants and lubricants.

\subsection{Hypoeutectic, Eutectic and Hypereutectic Aluminium-Silicon alloys}

Aluminium-Silicon system is a simple binary eutectic with limited solubility of aluminium in silicon and limited solubility of silicon in aluminium. There is only one invariant reaction, namely

$\mathrm{L} \rightarrow \alpha+\beta$ (eutectic)

In above equation, $\mathrm{L}$ is the liquid phase, $\alpha$ is predominantly aluminium, and $\beta$ is predominantly silicon. It is now widely accepted that the eutectic reaction takes place at $577^{\circ} \mathrm{C}$ and at a silicon level of $12.6 \%$.Depending on the $\mathrm{Si}$ concentration in weight percentage, the Al-Si alloy systems are divided into three major categories:

i. Hypoeutectic $(<12$ wt. \% Si)

ii. Eutectic (12-13 wt. \% Si)

iii. Hypereutectic (14-25 wt. \% Si). ${ }^{[4]}$

It is known that increasing the Si content results in an increase of the strength of hypoeutecticalloys and a decrease of the strength of hypereutectic alloys ${ }^{[5,6]}$.

\section{Preparation Of Al-Si Alloy Pin}

\subsection{Weight measurement of powder}

5 samples of Al-Si alloy are prepared. The following table shows weight of elemental-compositions taken in grams, in five different Al-Si p/m alloy samples for the preparation of alloy $\mathbf{P}$ : Al-9\% $\%$ Si, alloy $\mathbf{Q}$ : Al$12 \% \mathrm{Si}$,alloy R: Al-14\%Si,alloy $\mathbf{S}: \mathrm{Al}-17 \% \mathrm{Si}$ and alloy $\mathbf{T}: \mathrm{Al}-21 \% \mathrm{Si}$.

Table 1 Composition of Al-Si Alloy

\begin{tabular}{|l|l|l|l|l|l|}
\hline & Alloy P & Alloy Q & Alloy R & Alloy S & Alloy T \\
\hline Composition & Wt. (gms) & Wt. (gms) & Wt. (gms) & Wt. (gms) & Wt. (gms) \\
\hline $\mathrm{Si}$ & 9 & 12 & 14 & 17 & 21 \\
\hline $\mathrm{Cu}$ & 1.3 & 1.3 & 1.3 & 1.3 & 1.3 \\
\hline $\mathrm{Cr}$ & 0.1 & 0.1 & 0.1 & 0.1 & 0.1 \\
\hline $\mathrm{Fe}$ & 1.0 & 1.0 & 1.0 & 1.0 & 1.0 \\
\hline $\mathrm{Mg}$ & 1.0 & 1.0 & 1.0 & 1.0 & 1.0 \\
\hline $\mathrm{Ni}$ & 1.3 & 1.3 & 1.3 & 1.3 & 1.3 \\
\hline $\mathrm{Zn}$ & 0.25 & 0.25 & 0.25 & 0.25 & 0.25 \\
\hline $\mathrm{Ti}$ & 0.05 & 0.05 & 0.05 & 0.05 & 0.05 \\
\hline $\mathrm{Al}$ & 86 & 83 & 81 & 78 & 74 \\
\hline Total & 100 & 100 & 100 & 100 & 100 \\
\hline
\end{tabular}

\subsection{Mixing of powders}

Here ball milling type mixing method is adopted for proper mixing. The powder of each sample is kept in a cylindrical steel container of $55 \mathrm{~mm}$ diameter and $78 \mathrm{~mm}$ length. In the above container containing powder mix, 24 numbers of spherical steel balls (bicycle ball bearing) are put. Then the closed container is rotated at $160 \mathrm{rpm}$ in both clock wise and anti-clockwise direction for 30 minutes each. Steel balls are removed and the Powder is weighed in the digital weighing machine. The balls were rotated by holding it in a lathe chuck. 


\subsection{Die preparation}

$12 \mathrm{~mm}$ diameter circular cross section die and punch set is made for compacting circular pin. Another die of $30 \mathrm{~mm}$. dia. is made for holding the $12 \mathrm{~mm}$. diameter die. The length of both the dies are $80 \mathrm{~mm}$. Lower punch, upper punch and hollow cylindrical rod are $25 \mathrm{~mm}, 38 \mathrm{~mm}$ and $28 \mathrm{~cm}$ long respectively. The die sets are made of high strength tool steel (EN-8) with a highly polished die cavity. The clearance between die and punch is maintained as $0.1 \mathrm{~mm}$.

\subsection{Compaction of powder}

Compaction of different powders is done in the universal testing $\mathrm{m} / \mathrm{c}$ at different compaction pressures with the help of prepared die and punch. The corresponding pressures of compaction for Al-Si alloys are mentioned below.

Table 2: Compaction Pressures for different alloy samples.

\begin{tabular}{|l|l|c|}
\hline Alloys & Alloy composition & Compaction Pressure(KN) \\
\hline Alloy-P & $\mathrm{Al}-9 \% \mathrm{Si}$ & 70 \\
\hline Alloy-Q & $\mathrm{Al}-12 \% \mathrm{Si}$ & 76 \\
\hline Alloy-R & $\mathrm{Al}-14 \% \mathrm{Si}$ & 81 \\
\hline Alloy-S & $\mathrm{Al}-17 \% \mathrm{Si}$ & 85 \\
\hline Alloy-T & $\mathrm{Al}-21 \% \mathrm{Si}$ & 95 \\
\hline
\end{tabular}

3.5 Sintering of Green Compact

Sintering of the green compact of the 5 alloys is done in the vacuum furnace at $520^{\circ} \mathrm{C}$.

Table 3: Steps in sintering operation

\begin{tabular}{|l|l|}
\hline Segment -1 & $\begin{array}{l}\text { Compacts heated to } 400^{\circ} \mathrm{C} \text { starting from room temperature. Heating rate should be less } \\
\text { than } 4{ }^{\circ} \mathrm{C} \text { per minute to reduce stress in the compact. }\end{array}$ \\
\hline Segment -2 & $\begin{array}{l}\text { Green compacts are heated to } 520^{\circ} \mathrm{C} \text { starting from } 40^{\circ} \mathrm{C} \text {. Here heating rate should be less } \\
\text { than } 3.5^{\circ} \mathrm{C} \text { per minute to eliminate danger of thermal } \\
\text { Cracks in compacts. }\end{array}$ \\
\hline Segment -3 & $\begin{array}{l}\text { Temperature is held at } 520^{\circ} \mathrm{C} \text { for half an hour to complete chemical and diffusion } \\
\text { activities. }\end{array}$ \\
\hline
\end{tabular}

\subsection{Heat Treatment process}

The Heat treatment process is carried out in vacuum furnace. The process is controlled by programming through PID controller. The programming is done in three segments, for temperature up to $500^{\circ} \mathrm{C}$. After execution of the programme, the temperature is raised manually up to $800^{\circ} \mathrm{C}$. Then the furnace temperature is lowered and the samples are allowed to cool.

\subsection{Density measurement}

\section{Determination Of Mechanical Properties Of Al-Si Alloy Pin}

Two samples from each type of alloy are taken for density calculation. The functional parameters diameter (d) and length (l) are measured by vernier caliper. Mean diameter (dm) and mean length $(\mathrm{lm})$ of each sample are obtained. Volume of each sample is calculated.Alloy samples are weighed by Digital Weighing Machine and Mean Mass (Mm) is calculatedfor each sample.Densities $(\rho)$ of each sample are calculated by taking volume $(\mathrm{V})$ and mean mass $(\mathrm{Mm})$.

\subsection{Measurement Of Total Fractional Porosity $(\gamma)$} relation $^{[7]}$ :

Thetotal fractional porosity $(\gamma)$ present in the sintered component may be evaluated from thefollowing

$\gamma=1-(\gamma p / \gamma \mathrm{s})$

Where, $\gamma=$ Fractional porosity of powder metallurgy component.

$\gamma \mathrm{p}=$ Density of the sintered component.

$\gamma \mathrm{s}=$ Density of the solid material.

Density of sintered component $(\gamma p)$ may be evaluated by the following relation:

$\gamma \mathrm{p}=(\mathrm{Mp} / \mathrm{Vp})$

Where, $\mathrm{Mp}=$ Mass of sintered component.

$\mathrm{Vp}=$ Volume of sintered component.

Density of solid material $(\gamma \mathrm{s})$ which is an alloy may be evaluated by the following relation:

$\gamma \mathrm{s}=\gamma(\gamma \mathrm{i}, \mathrm{xi})$ 
Where, $\gamma \mathrm{i}=$ Density of the individual alloying element.

$\mathrm{xi}=$ Mass fraction of the individual alloying element present in the alloy.

\subsection{Measurement of Hardness Number}

Hardness measurement for each sample of alloys is carried out in a Rockwell Hardness Testing Machine. For hardness measurement B-Scale was selected where major load applied was $100 \mathrm{Kgf}$ and minor load applied was $10 \mathrm{Kgf}$ and 1/16" Hardened Steel Ball is used as Indenter. Four indentations are made on the surface of each sample and the hardness values as obtained from the machine are recorded.

\section{Determination Of Tribologzical Properties}

The Tribological behaviour of cylindrical pins is investigated with the help of Pin-On-Disc test. The disc is made of hardened steel (EN-310) and driven by a motor through a reduction gearbox. This allows the disc to rotate a number of specified speeds within a speed range ${ }^{[8]}$. The disc has a diameter of $100 \mathrm{~mm}$. and thickness of $8 \mathrm{~mm}$. the specimen is held on the rotating disc with the help of pin holder, in turn is attached to load cell which helps to determine the frictional force developed between the loaded specimen and rotating disc. Before conducting each test all the samples (pins) are polished by using (Grade: 120) emery paper. The surface of the disc is also cleaned with jute to remove any dirt or grease. The height lost due to wear in $\mu \mathrm{m}$ of each sample (pins) is recorded after each rotation (Test) as shown by the Machine.Wear measurement for each sample of five alloys is carried out in a Wear Friction Monitor. Wear of each sample (pin of $12 \mathrm{~mm}$. diameter) in terms of height loss in $\mu \mathrm{m}$ has been measured by varying the sliding speed 200 RPM, 400 RPM, 600 RPM and 800 RPM and the applied load has been varied 20N, 40N, 60N and 80N for each Sliding Speed respectively by keeping track diameter fixed at $70 \mathrm{~mm}$.

\subsection{Measurement of co-efficient of friction.}

The frictional co-efficient may be measured by using Coulomb's law. Dry friction or Coulomb's friction refers to the tangential component of the contact force between two dry surfaces in relative movement. The co-efficient of friction:

$$
\mu=\mathrm{Fr} / \mathrm{F}
$$

Where, Fr= Frictional Force and $\mathrm{F}=$ force applied.

\subsection{Measurement of wear rate.}

The Wear rate may be calculated by using the following relationship ${ }^{[9]}$;

$$
\mathrm{Wr}=(\mathrm{M} 1-\mathrm{Mf}) /[\mathrm{t} \times(\pi \mathrm{DN} / 1000)\}
$$

Where, $\mathrm{MI}=$ initial mass $(\mathrm{gm}$.$) .$

$\mathrm{Mf}=$ final mass $(\mathrm{gm}$.$) .$

$\mathrm{t}=$ time of rotation in minute.

$\mathrm{D}=$ Track diameter $(\mathrm{mm})$.

$\mathrm{N}=\mathrm{rpm}$

$\mathrm{Wr}=\mathrm{gm} . /$ meter of rotation

Sliding Speed $=\Pi D N / 1000 \mathrm{~m} / \mathrm{min}$

\section{Results And Discussions}

6.1 Effect of Composition on Density.

Mass and volume for each sample of five alloys are measured with the help of Digital Balance and Vernier Caliper respectively, which are being used to calculate the Density of the same. Acquired data are listed below in the following table:-

Table 4: Dimensions and volume of samples

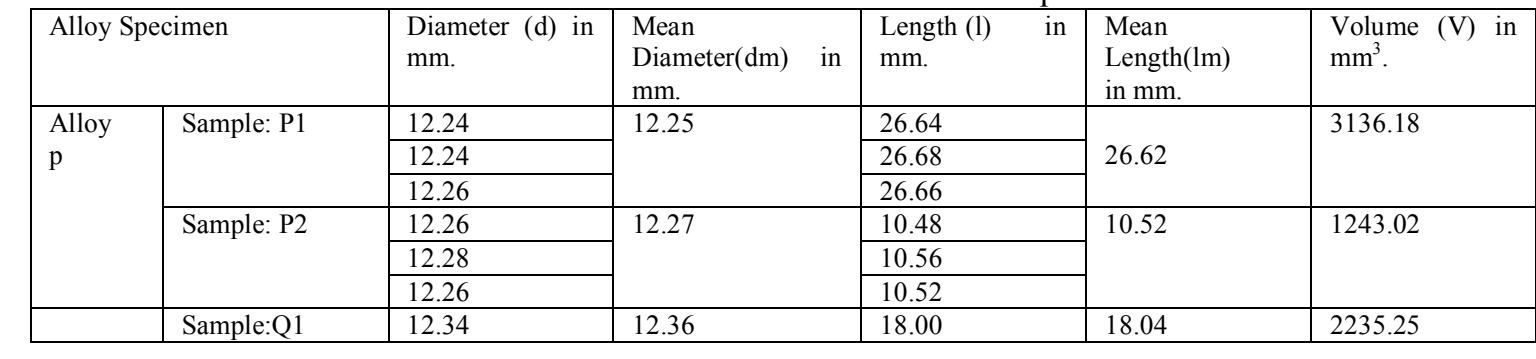


Study of Mechanical and Tribological Properties of Al-Si alloy Prepared by Powder ......

\begin{tabular}{|c|c|c|c|c|c|c|}
\hline \multirow{5}{*}{ Alloy Q } & & 12.38 & & 18.04 & & \\
\hline & & 12.38 & & 18.08 & & \\
\hline & \multirow[t]{3}{*}{ Sample:Q2 } & 12.40 & \multirow[t]{3}{*}{12.39} & 10.38 & \multirow[t]{3}{*}{10.42} & \multirow[t]{3}{*}{1255.42} \\
\hline & & 12.38 & & 10.46 & & \\
\hline & & 12.38 & & 10.42 & & \\
\hline \multirow{6}{*}{$\begin{array}{l}\text { Alloy } \\
\text { R }\end{array}$} & \multirow[t]{3}{*}{ Sample:R1 } & 12.40 & \multirow[t]{3}{*}{12.42} & 20.90 & \multirow[t]{3}{*}{20.96} & \multirow[t]{3}{*}{2537.80} \\
\hline & & 12.44 & & 21.02 & & \\
\hline & & 12.42 & & 20.96 & & \\
\hline & \multirow[t]{3}{*}{ Sample:R2 } & 12.46 & \multirow[t]{3}{*}{12.46} & 11.16 & \multirow[t]{3}{*}{11.22} & \multirow[t]{3}{*}{1367.31} \\
\hline & & 12.48 & & 11.28 & & \\
\hline & & 12.44 & & 11.22 & & \\
\hline \multirow{6}{*}{$\begin{array}{l}\text { Alloy } \\
\text { S }\end{array}$} & \multirow[t]{3}{*}{ Sample:S1 } & 12.54 & \multirow[t]{3}{*}{12.56} & 17.02 & \multirow[t]{3}{*}{16.98} & \multirow[t]{3}{*}{2102.29} \\
\hline & & 12.58 & & 17.08 & & \\
\hline & & 12.58 & & 16.90 & & \\
\hline & \multirow[t]{3}{*}{ Sample:S2 } & 12.48 & \multirow[t]{3}{*}{12.50} & 12.00 & \multirow[t]{3}{*}{12.12} & \multirow[t]{3}{*}{1486.49} \\
\hline & & 12.50 & & 12.24 & & \\
\hline & & 12.52 & & 12.12 & & \\
\hline \multirow{6}{*}{$\begin{array}{l}\text { Alloy } \\
\mathrm{T}\end{array}$} & \multirow[t]{3}{*}{ Sample:T1 } & 12.74 & \multirow[t]{3}{*}{12.76} & 22.26 & \multirow[t]{3}{*}{22.27} & \multirow[t]{3}{*}{2846.06} \\
\hline & & 12.78 & & 22.28 & & \\
\hline & & 12.76 & & 22.28 & & \\
\hline & \multirow[t]{3}{*}{ Sample:T2 } & 12.80 & \multirow[t]{3}{*}{12.78} & 11.74 & \multirow[t]{3}{*}{11.76} & \multirow[t]{3}{*}{1507.70} \\
\hline & & 12.78 & & 11.76 & & \\
\hline & & 12.78 & & 11.78 & & \\
\hline
\end{tabular}

Table 5: Mass, Volume and Mean Density of Samples

\begin{tabular}{|c|c|c|c|c|c|c|}
\hline Alloy & & $\begin{array}{l}\text { Specimen } \\
\text { Mass (M) } \\
\text { in gm. }\end{array}$ & $\begin{array}{l}\text { Mean } \\
\text { Mass } \\
(\mathrm{Mm}) \\
\text { in gm. }\end{array}$ & $\begin{array}{l}\text { Volume } \\
\text { (V) } \\
\text { in } \mathrm{mm} 3\end{array}$ & $\begin{array}{l}\text { Density } \\
(\rho) \\
\text { in } \\
\mathrm{gm} . / \mathrm{cm} 3\end{array}$ & $\begin{array}{l}\text { Mean } \\
\text { Density }(\rho \mathrm{m}) \text { in } \\
\mathrm{gm} . / \mathrm{cm} 3\end{array}$ \\
\hline \multirow{6}{*}{$\begin{array}{l}\text { Alloy } \\
\text { P }\end{array}$} & \multirow[t]{3}{*}{ Sample:P1 } & 7.546 & \multirow[t]{3}{*}{7.547} & \multirow[t]{3}{*}{3136.18} & \multirow[t]{3}{*}{2.400} & \multirow{6}{*}{2.415} \\
\hline & & 7.548 & & & & \\
\hline & & 7.548 & & & & \\
\hline & \multirow[t]{3}{*}{ Sample:P2 } & 3.021 & \multirow[t]{3}{*}{3.020} & \multirow[t]{3}{*}{1243.02} & \multirow[t]{3}{*}{2.430} & \\
\hline & & 3.019 & & & & \\
\hline & & 3.020 & & & & \\
\hline \multirow{6}{*}{$\begin{array}{l}\text { Alloy } \\
\text { Q }\end{array}$} & \multirow[t]{3}{*}{ Sample:Q1 } & 5.220 & \multirow[t]{3}{*}{5.220} & \multirow[t]{3}{*}{2235.25} & \multirow[t]{3}{*}{2.330} & \multirow{6}{*}{2.350} \\
\hline & & 5.219 & & & & \\
\hline & & 5.220 & & & & \\
\hline & \multirow[t]{3}{*}{ Sample:Q2 } & 2.973 & \multirow[t]{3}{*}{2.975} & \multirow[t]{3}{*}{1255.42} & \multirow[t]{3}{*}{2.370} & \\
\hline & & 2.975 & & & & \\
\hline & & 2.975 & & & & \\
\hline \multirow{6}{*}{$\begin{array}{l}\text { Alloy } \\
\text { R }\end{array}$} & \multirow[t]{3}{*}{ Sample:R1 } & 5.877 & \multirow[t]{3}{*}{5.879} & \multirow[t]{3}{*}{2537.80} & \multirow[t]{3}{*}{2.316} & \multirow{6}{*}{2.314} \\
\hline & & 5.881 & & & & \\
\hline & & 5.879 & & & & \\
\hline & \multirow[t]{3}{*}{ Sample:R2 } & 3.159 & \multirow[t]{3}{*}{3.161} & \multirow[t]{3}{*}{1367.31} & \multirow[t]{3}{*}{2.312} & \\
\hline & & 3.159 & & & & \\
\hline & & 3.163 & & & & \\
\hline Alloy & Sample:S1 & 4.755 & 4.758 & 2102.29 & 2.263 & \\
\hline $\mathrm{S}$ & & 4.758 & & & & \\
\hline & & 4.761 & & & & \\
\hline & Sample:S2 & 3.370 & 3.371 & 1486.49 & 2.268 & 2.266 \\
\hline & & 3.372 & & & & \\
\hline & & 3.371 & & & & \\
\hline Alloy & Sample:T1 & 6.190 & 6.188 & 2846.06 & 2.174 & 2.178 \\
\hline $\mathrm{T}$ & & 6.191 & & & & \\
\hline & & 6.186 & & & & \\
\hline & Sample:T2 & 3.285 & 3.288 & 1507.70 & 2.181 & \\
\hline & & 3.291 & & & & \\
\hline & & 3.288 & & & & \\
\hline
\end{tabular}




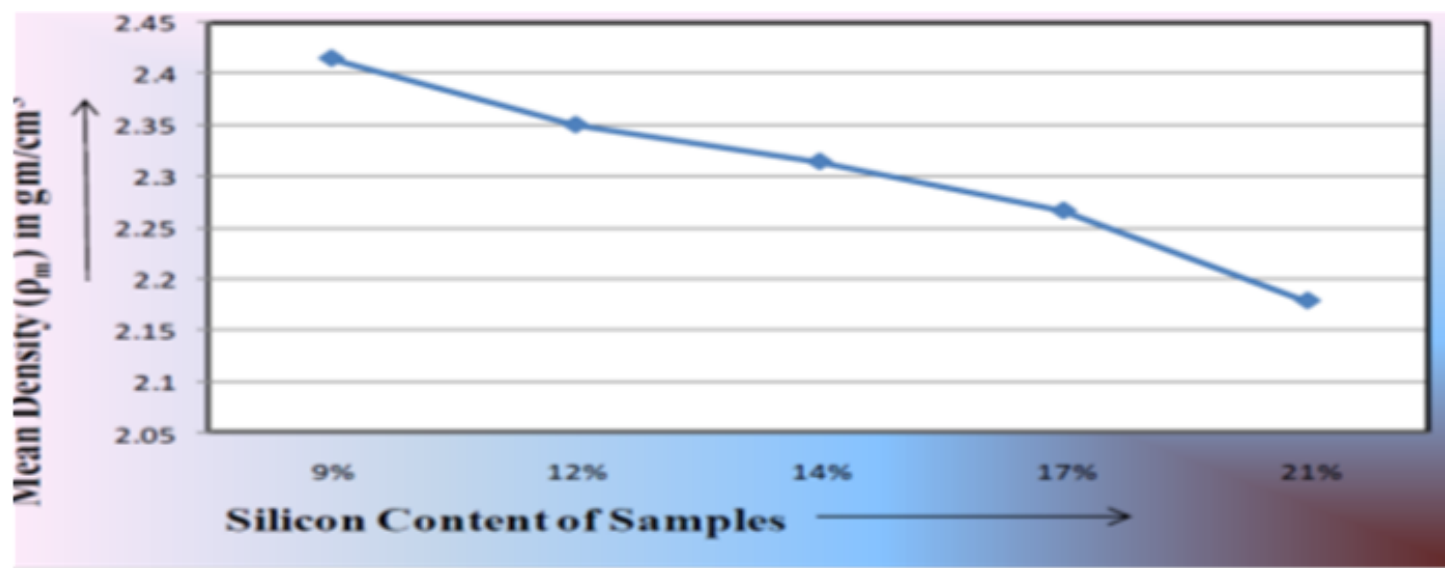

Figure 1 Density of Samples at different Silicon Content

The Densities for alloys Al-9\%, Al-12\%, Al-14\%, Al-17\% and Al-21\% are found to be $2.415 \mathrm{gms} / \mathrm{cm} 3,2.350$ $\mathrm{gms} / \mathrm{cm} 3,2.314 \mathrm{gms} / \mathrm{cm} 3,2.266 \mathrm{gms} / \mathrm{cm} 3$ and $2.178 \mathrm{gms} / \mathrm{cm} 3$ respectively.

It is observed from the above data that the density of samples is decreasing with the increase in Silicon content. It is due tSilicon content The density of alloy decreases with increase in silicon content as it has lower density(i.e. $2.34 \mathrm{gms} / \mathrm{cm} 3$ ) than that of Aluminium (i.e. $2.67 \mathrm{gms} / \mathrm{cm} 3$ ).

\subsection{Effect of Composition on Porosity}

Table 6: Fractional porosity of samples

\begin{tabular}{|l|l|l|l|l|l|}
\hline $\begin{array}{l}\text { Total } \\
\text { Fractional } \\
\text { Porosity }(\gamma)\end{array}$ & $\begin{array}{l}\text { Alloy P } \\
(\mathrm{Al}-9 \% \mathrm{Si})\end{array}$ & $\begin{array}{l}\text { Alloy Q } \\
(\mathrm{Al}-12 \% \mathrm{Si})\end{array}$ & $\begin{array}{l}\text { Alloy R } \\
(\mathrm{Al}-14 \% \mathrm{Si})\end{array}$ & $\begin{array}{l}\text { Alloy S } \\
(\mathrm{Al}-17 \% \mathrm{Si})\end{array}$ & $\begin{array}{l}\text { Alloy T } \\
(\mathrm{Al}-21 \% \mathrm{Si})\end{array}$ \\
\cline { 2 - 6 } & 0.16 & 0.18 & 0.19 & 0.20 & 0.23 \\
\hline
\end{tabular}

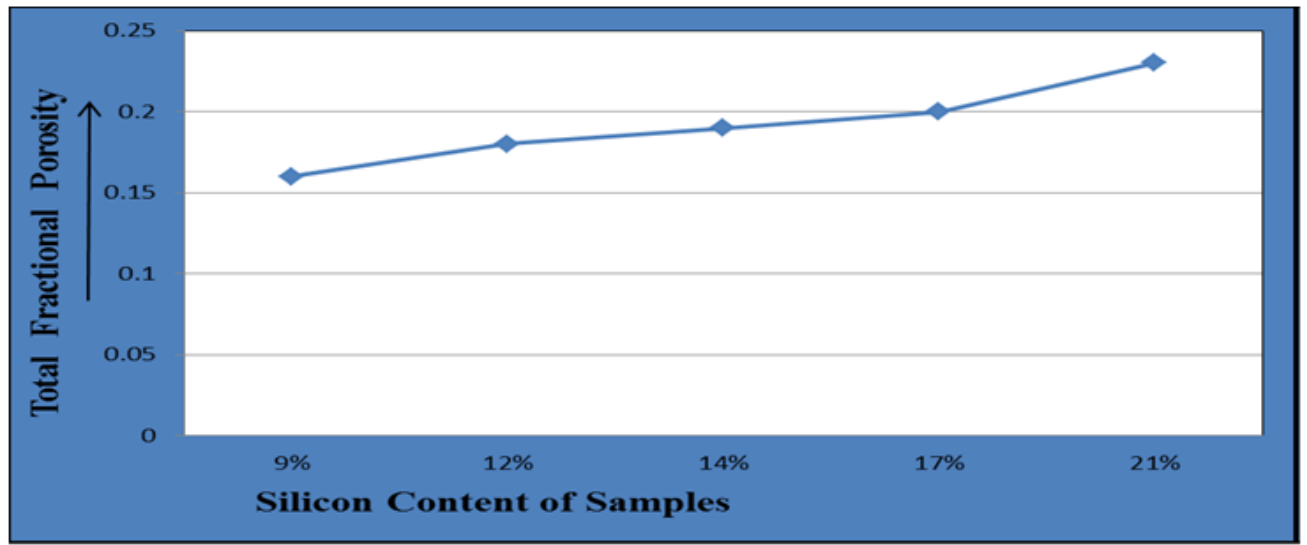

Figure 2: Fractional Porosity of Samples at different Silicon Content

It is observed from the above data that the porosity of the samples is increasing with the increase of Silicon amount. It may be due to the decrease in density of the alloy samples with increasing Silicon amount. So, it can be concluded that the Porosity of the alloy is inversely proportional to the Density of the alloy samples.

\subsection{Effect of Composition on Hardness}

Table 7: Hardness of alloy samples

\begin{tabular}{|c|c|c|c|c|}
\hline \multicolumn{2}{|c|}{ Alloy Specimen } & \multirow{2}{*}{$\begin{array}{l}\text { Hardness } \\
\text { (HRB) }\end{array}$} & \multirow{2}{*}{$\begin{array}{l}\text { Average } \\
\text { Hardness (HRB) } \\
66.00\end{array}$} & \multirow{2}{*}{$\begin{array}{l}\text { Average } \\
\text { Hardness } \\
\text { (HRB) }\end{array}$} \\
\hline \multirow{7}{*}{$\begin{array}{l}\text { Alloy } \\
\text { P }\end{array}$} & \multirow[t]{4}{*}{ Surface: 1} & & & \\
\hline & & 65 & & \\
\hline & & 66 & & \\
\hline & & 67 & & \\
\hline & \multirow[t]{3}{*}{ Surface:2 } & 64 & \multirow[t]{3}{*}{65.00} & \\
\hline & & 66 & & \\
\hline & & 65 & & \\
\hline
\end{tabular}


Study of Mechanical and Tribological Properties of Al-Si alloy Prepared by Powder ......

\begin{tabular}{|c|c|c|c|c|}
\hline & & 65 & & \\
\hline \multirow{8}{*}{$\begin{array}{l}\text { Alloy } \\
\text { Q }\end{array}$} & \multirow[t]{4}{*}{ Surface: 1} & 68 & \multirow[b]{4}{*}{68.75} & \multirow{8}{*}{69.00} \\
\hline & & 69 & & \\
\hline & & 68 & & \\
\hline & & 70 & & \\
\hline & \multirow[t]{4}{*}{ Surface:2 } & 70 & \multirow[t]{4}{*}{69.25} & \\
\hline & & 70 & & \\
\hline & & 69 & & \\
\hline & & 68 & & \\
\hline \multirow{8}{*}{$\begin{array}{l}\text { Alloy } \\
\text { R }\end{array}$} & \multirow[t]{4}{*}{ Surface: 1} & 72 & \multirow[t]{4}{*}{72.00} & \multirow[t]{8}{*}{72.13} \\
\hline & & 73 & & \\
\hline & & 72 & & \\
\hline & & 71 & & \\
\hline & \multirow[t]{4}{*}{ Surface:2 } & 73 & \multirow[t]{4}{*}{72.25} & \\
\hline & & 73 & & \\
\hline & & 72 & & \\
\hline & & 71 & & \\
\hline \multirow{8}{*}{$\begin{array}{l}\text { Alloy } \\
\text { S }\end{array}$} & \multirow[t]{4}{*}{ Surface: 1} & 75 & \multirow[t]{4}{*}{76.00} & \multirow[t]{8}{*}{76.50} \\
\hline & & 77 & & \\
\hline & & 76 & & \\
\hline & & 76 & & \\
\hline & \multirow[t]{4}{*}{ Surface: 2} & 77 & \multirow[t]{4}{*}{77.00} & \\
\hline & & 78 & & \\
\hline & & 77 & & \\
\hline & & 76 & & \\
\hline \multirow{8}{*}{$\begin{array}{l}\text { Alloy } \\
\mathrm{T}\end{array}$} & \multirow[t]{4}{*}{ Surface: 1} & 82 & \multirow[t]{4}{*}{82.25} & \multirow[t]{8}{*}{82.13} \\
\hline & & 81 & & \\
\hline & & 84 & & \\
\hline & & 82 & & \\
\hline & \multirow[t]{4}{*}{ Surface:2 } & 81 & \multirow[t]{4}{*}{82.00} & \\
\hline & & 81 & & \\
\hline & & 83 & & \\
\hline & & 84 & & \\
\hline
\end{tabular}

The Brinell hardness numbers (HRB) for alloys $\mathrm{Al}-9 \% \mathrm{Si}, \mathrm{Al}-12 \% \mathrm{Si}, \mathrm{Al}-14 \% \mathrm{Si}, \mathrm{Al}-17 \% \mathrm{Si}$ and $\mathrm{Al}-$ $21 \% \mathrm{Si}$ are found to be $65.50,69.00,72.13,76.50$ and 82.13 respectively. This shows that hardness of the Al-Si alloy increases with the increase in the weight percentage of silicon. This is due to the increment of silicon amount which is harder than Aluminium.

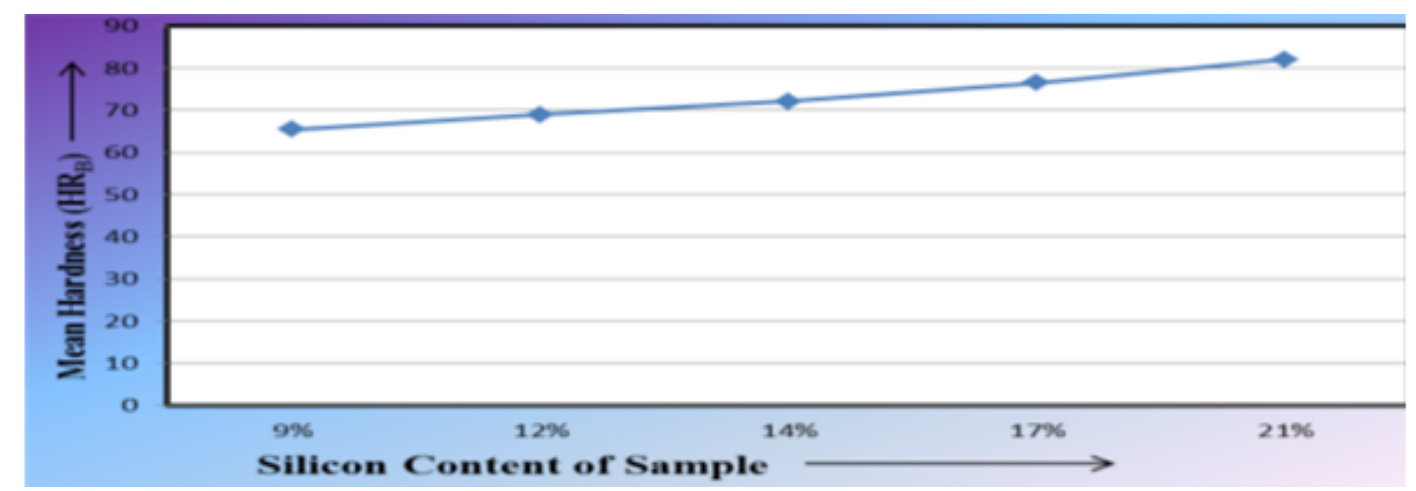

Figure 3 Mean Hardness of alloy with varying composition of silicon

\subsection{Effect of Composition on Wearing Property}

Wear measurement for each sample of five alloys is carried out in a Wear Friction Monitoring Machine. Wear of Specimen is measured by varying the Sliding Speed( 200RPM, 400RPM, 600RPM and $800 \mathrm{RPM}$ )and the applied load ( $20 \mathrm{~N}, 40 \mathrm{~N}, 60 \mathrm{~N}, 80 \mathrm{~N}$ for each Sliding Speed respectively). The Wears as shown by the wear and friction monitoring machine are listed below.

Table 8: Wear of Al-Si alloy specimen at applied load 20N

\begin{tabular}{|l|l|l|l|l|l|l|}
\hline $\begin{array}{l}\text { Load in } \\
(\mathrm{N})\end{array}$ & $\begin{array}{l}\text { Speed in } \\
(\mathrm{RPM})\end{array}$ & $\begin{array}{l}\text { Alloy-P } \\
\text { Wear in }(\mu \mathrm{m})\end{array}$ & $\begin{array}{l}\text { Alloy-Q } \\
\text { Wear in }(\mu \mathrm{m})\end{array}$ & $\begin{array}{l}\text { Alloy-R } \\
\text { Wear in }(\mu \mathrm{m})\end{array}$ & $\begin{array}{l}\text { Alloy-S } \\
\text { Wear in }(\mu \mathrm{m})\end{array}$ & $\begin{array}{l}\text { Alloy-T } \\
\text { Wear in }(\mu \mathrm{m})\end{array}$ \\
\hline 20 & 200 & 61 & 40 & 27 & 20 & 11 \\
\hline 20 & 400 & 93 & 61 & 40 & 28 & 17 \\
\hline 20 & 600 & 133 & 96 & 66 & 45 & 32 \\
\hline 20 & 800 & 182 & 130 & 95 & 64 & 50 \\
\hline
\end{tabular}


Study of Mechanical and Tribological Properties of Al-Si alloy Prepared by Powder ......

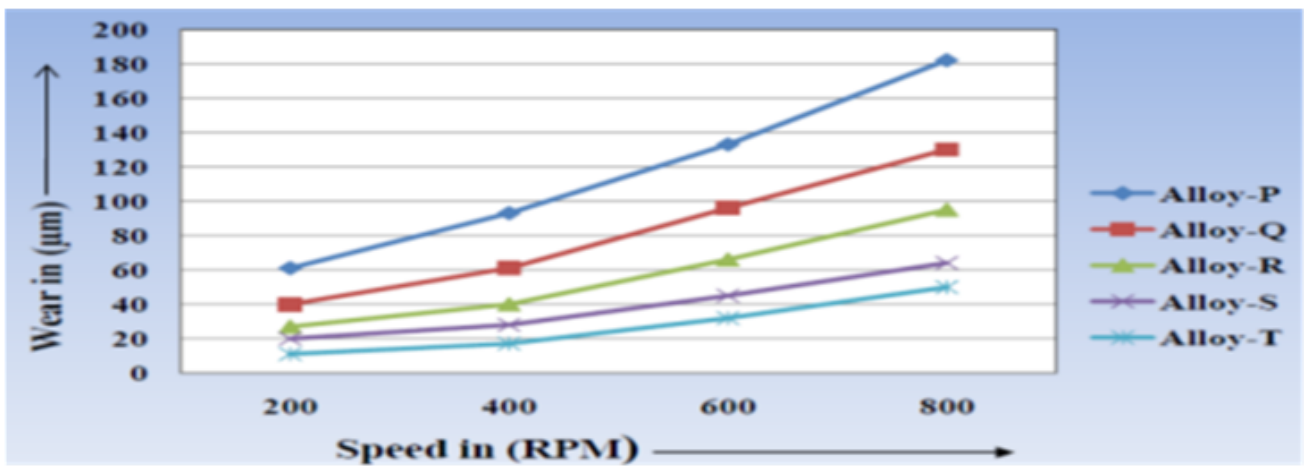

Figure 4: Wear Vs Sliding Speed of Al-Si Alloy Specimen at 20N applied Load

Table 9: Wear of Al-Si alloy specimen at applied load 40N

\begin{tabular}{|l|l|l|l|l|l|l|}
\hline $\begin{array}{l}\text { Load in } \\
(\mathrm{N})\end{array}$ & $\begin{array}{l}\text { Speed in } \\
(\mathrm{RPM})\end{array}$ & $\begin{array}{l}\text { Alloy-P } \\
\text { Wear in }(\mu \mathrm{m})\end{array}$ & $\begin{array}{l}\text { Alloy-Q } \\
\text { Wear in }(\mu \mathrm{m})\end{array}$ & $\begin{array}{l}\text { Alloy-R } \\
\text { Wear in }(\mu \mathrm{m})\end{array}$ & $\begin{array}{l}\text { Alloy-S } \\
\text { Wear in }(\mu \mathrm{m})\end{array}$ & $\begin{array}{l}\text { Alloy-T } \\
\text { Wear in }(\mu \mathrm{m})\end{array}$ \\
\hline 80 & 200 & 195 & 176 & 165 & 156 & 147 \\
\hline 80 & 400 & 231 & 198 & 179 & 164 & 155 \\
\hline 80 & 600 & 271 & 228 & 205 & 181 & 173 \\
\hline 80 & 800 & 320 & 272 & 235 & 201 & 191 \\
\hline
\end{tabular}

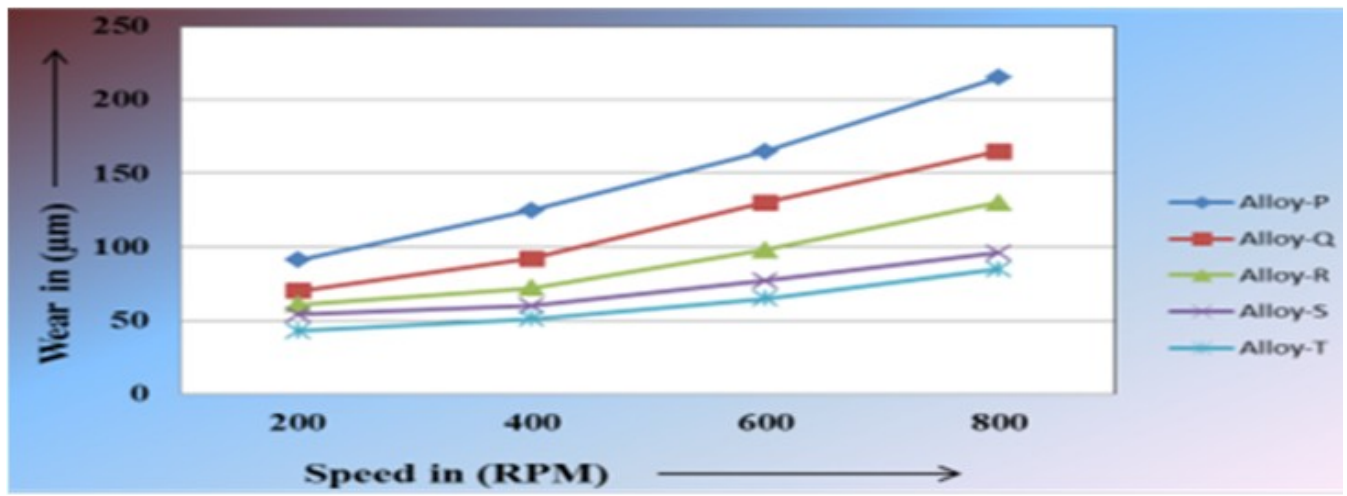

Figure 5: Wear Vs. Sliding Speed of Al-Si Alloy Specimen at 40N applied Load

Table 10: Wear of Al-Si alloy specimen at applied load $60 \mathrm{~N}$

\begin{tabular}{|l|l|l|l|l|l|l|}
\hline $\begin{array}{l}\text { Load in } \\
(\mathrm{N})\end{array}$ & $\begin{array}{l}\text { Speed in } \\
(\mathrm{RPM})\end{array}$ & $\begin{array}{l}\text { Alloy-P } \\
\text { Wear in }(\mu \mathrm{m})\end{array}$ & $\begin{array}{l}\text { Alloy-Q } \\
\text { Wear in }(\mu \mathrm{m})\end{array}$ & $\begin{array}{l}\text { Alloy-R } \\
\text { Wear in }(\mu \mathrm{m})\end{array}$ & $\begin{array}{l}\text { Alloy-S } \\
\text { Wear in }(\mu \mathrm{m})\end{array}$ & $\begin{array}{l}\text { Alloy-T } \\
\text { Wear in }(\mu \mathrm{m})\end{array}$ \\
\hline 60 & 200 & 133 & 112 & 103 & 95 & 85 \\
\hline 60 & 400 & 169 & 135 & 115 & 102 & 93 \\
\hline 60 & 600 & 209 & 170 & 142 & 119 & 109 \\
\hline 60 & 800 & 257 & 210 & 173 & 138 & 128 \\
\hline
\end{tabular}

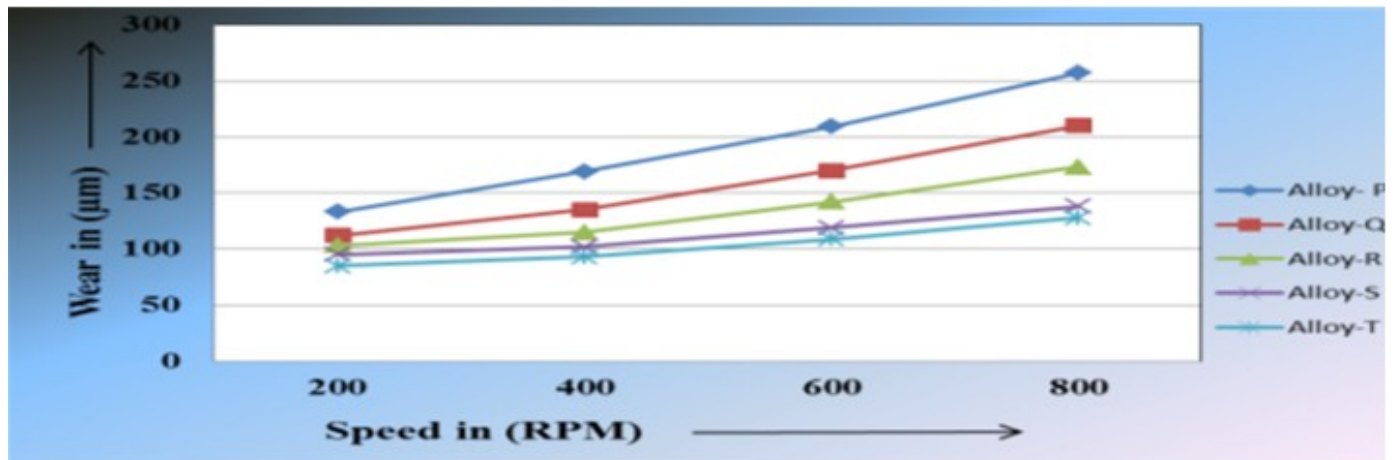

Figure 6: Wear Vs Sliding Speed of Al-Si Alloy Specimen at 60N applied Load 
Table 11: Wear of Al-Si alloy specimen at applied load $80 \mathrm{~N}$

\begin{tabular}{|c|c|c|c|c|c|c|}
\hline $\begin{array}{l}\text { Load in } \\
(\mathrm{N})\end{array}$ & $\begin{array}{l}\text { Speed in } \\
(\mathrm{RPM})\end{array}$ & $\begin{array}{l}\text { Alloy-P } \\
\text { Wear in }(\mu \mathrm{m})\end{array}$ & $\begin{array}{l}\text { Alloy-Q } \\
\text { Wear in }(\mu \mathrm{m})\end{array}$ & $\begin{array}{l}\text { Alloy-R } \\
\text { Wear in }(\mu \mathrm{m})\end{array}$ & $\begin{array}{l}\text { Alloy-S } \\
\text { Wear in }(\mu \mathrm{m})\end{array}$ & $\begin{array}{l}\text { Alloy-T } \\
\text { Wear in }(\mu \mathrm{m})\end{array}$ \\
\hline 80 & 200 & 195 & 176 & 165 & 156 & 147 \\
\hline 80 & 400 & 231 & 198 & 179 & 164 & 155 \\
\hline 80 & 600 & 271 & 228 & 205 & 181 & 173 \\
\hline 80 & 800 & 320 & 272 & 235 & 201 & 191 \\
\hline
\end{tabular}

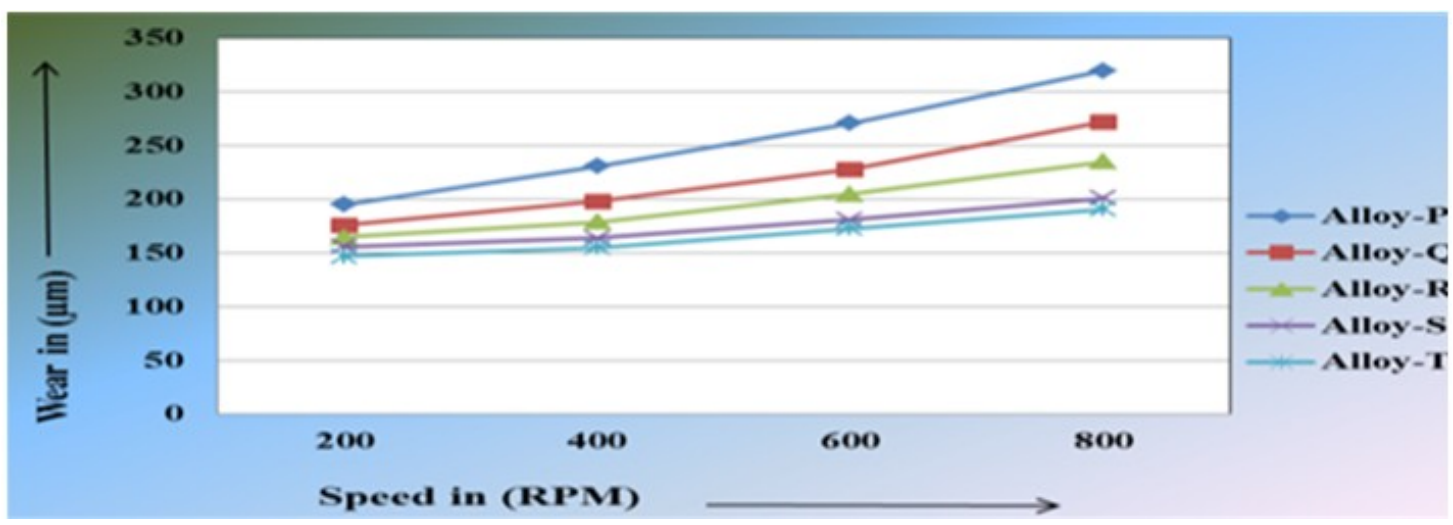

Figure 7: Wear Vs Sliding Speed of Al-Si Alloy Specimen at 80N applied Load

It is noticed that the height loss due to wear decreases with the increase in the percentage of silicon. The decrease in height loss with increasing percentage of silicon can be attributed to the presence of hard silicon particles adhered to the alloy. It is also noticed that due to the variation of the applied load the wear behavior is affected. The wear increases with the increase of applied load. This happens due to more frictional forces generated by more applied loads.

\subsection{Composition Analysis}

The following wt $\%$ of $\mathrm{Al} \& \mathrm{Si}$ are taken from the report given by the Eastern Testing Laboratory.

Table 12: Weight percentage of $\mathrm{Al}$ and Si Present in Al-Si $\mathrm{p} / \mathrm{m}$ alloys

\begin{tabular}{|l|l|l|}
\hline Alloy Specimen & Silicon (\%) & Aluminium (\%) \\
\hline Alloy P & 9.03 & 85.86 \\
\hline Alloy Q & 12.02 & 82.87 \\
\hline Alloy R & 13.95 & 81.06 \\
\hline Alloy S & 16.95 & 78.13 \\
\hline Alloy T & 20.91 & 74.15 \\
\hline
\end{tabular}

The weight percentage of Silicon in Alloy-P (Al-9\%Si)and Alloy-Q (Al-12\% $\%$ Si)is found to be $9.03 \%$ and $12.02 \%$ which is very close to $9 \%$ and $12 \%$ respectively. This suggests that sintered structure obtained is very sound. It can be seen that there is no loss of silicon and Aluminium in evaporation. The weight percentage of Silicon in Alloy-R (Al-14\%Si), Alloy-S (Al-17\% Si) and Alloy-T (Al-21\% Si) is found to be 13.95, 16.95 and 20.91 which are still close to $14 \%, 17 \%$ and $21 \%$ respectively. This may happen due to some loss of Silicon in evaporation or this may be minor manual fault.

\section{Acknowledgements}

I am grateful to assistant professor Mr Santanu Chakroboarty, for his constant encouragement and support in this endeavor. I extend my gratitude to HOD Mechanical Department S.M.I.T Dr. B.B Pradhan for his support and for allowing us to use different labs for different experiments. I would like to extend my gratefulness towards Eastern Testing Laboratory, Kolkata for conducting composition test for us. Lastly I would like to thank all the lab assistants of Mechanical department S.M.I.T for their support.

\section{References}

[1]. Gaber A., Gaffar M.A., Mostafa M.S., Abo Zeid E.F. ; Precipitation kinetics of Al-1.12 Mg2Si-0.35 Si and Al-1.07 Mg2Si-0.33 Cu alloys, J. Alloys Compd., Vol. 429 (2007), pp. 167-175.

[2]. Davis J. R., Aluminum and aluminum alloys, J. R. Davis \& Associates, ASM International. Handbook Committee, pp 3-8.

[3]. http://www.keytometals.com/Article80.htm, retrieved on 16th April 2011.1

[4]. Murray J.L., McAlister A.J.; ASM Handbook Volume 3: Alloy Phase Diagrams.

[5]. M. Gupta, S. Ling, J. Alloys Compd. 287 (1999) 284-294.

[6]. S.P. Nikanorova,*, M.P. Volkova, V.N. Gurina, Yu.A. Burenkova, L.I. Derkachenkoa,B.K. Kardasheva, L.L. Regelb, W.R. WilcoxbStructural and mechanical properties of Al-Si alloys obtained by fast cooling of a levitated meltelsevier/Materials Science 
and Engineering A 390 (2005) 63-69

[7]. Angelo P.C "Powder Metallurgy: science, Technology and Applications (C) 2008 by Prentice- Hall of India Private Limited New Delhi 110001

[8]. G 99 - 95a (Reapproved 2000) Standard Test Method forWear Testing with a Pin-on-Disk Apparatus1copyrighted by ASTM, 100 Barr Harbor Drive, PO Box C700,West Conshohocken, PA 19428-2959, United States.

[9]. Hani Aziz Ameen, Khairia Salman Hassain, and Ethar Mohamed Mhdi Mubarak, Effect of Loads, Sliding speeds and times on the wear rate for different materials.ISSN; 2153-649X doi:10.5251/ajsir.2011.2.99.106 